\title{
Socio-economic inequalities in profiles of social integration across adulthood: evidence from a British birth cohort study
}

\author{
Kate Harvey \\ Dr Graciela Muniz Terrera \\ Professor Diana Kuh \\ Dr Mai Stafford \\ k.harvey2@nhs.net
}

\author{
MRC Unit for Lifelong Health and Ageing \\ at University College London
}

(Received January 2014 Revised May 2014)

$\underline{\text { http://dx.doi.org/10.14301/llcs.v5i3.284 }}$

\section{Abstract}

Social integration in older age is a key quality of life component and is associated with reduced mortality and morbidity risk. There are socio-economic differences in social integration, but the influence of different indicators of socio-economic position on long-term change in social integration at older ages is not known. This study aimed to identify profiles of social integration across adulthood and explore the impact of various socio-economic indicators at different ages. Data were drawn from the MRC National Survey of Health and Development. A latent class analysis used measures of contact with friends and family, participation in group activities and marital status at ages 36, 43 and 60-64 to identify profiles of change in social integration for men and women. One-step analyses related profiles to father's occupation-based socio-economic position, own educational attainment and head of household occupation-based socio-economic position. Four profiles of social integration were identified for men: high and maintained, married; medium and maintained, married; declining, married; and declining, unmarried. Higher head of household occupation and educational attainment were associated with greater likelihood of maintained integration. Four profiles of social integration were also identified for women: high and maintained, married; high and maintained, unmarried; declining group participation, unmarried; and declining group participation, married. Higher socio-economic position on all indicators was associated with greater likelihood of maintained integration. Lower socio-economic groups are more likely to experience declining social integration by early old age. Support to promote social integration may be particularly important for those with lower occupational grade or education.

Keywords: United Kingdom; social integration; social engagement; socio-economic position; gender; cohort; longitudinal; National Survey of Health and Development

\section{Background}

\section{Social integration}

Social integration has been defined as attachment to society through ties to family and friends and formal links to community institutions (Berkman, Glass, Brissette, \& Seeman, 2000; Fothergill et al., 2011). As such, it is a structural measure of the quantity of social networks as opposed to a functional measure of the subjective experience of social support or loneliness, and is commonly assessed through the construction of indices comprising contact with friends and family, participation in clubs or associations and marital 
status (Berkman, \& Syme, 1979; Berkman et al., 2004; Stringhini et al., 2012; Vonneilich et al., 2011).

Studies suggest that social integration changes across the life course, with a small decrease in network size at older ages and an increasing emphasis on contact with family members as opposed to non-family members (Kalmijn, 2012). One explanation for this pattern of change is 'socioemotional selectivity theory' (Carstensen, Isacowitz, \& Charles, 1999) whereby older individuals prioritise social relationships that provide immediate emotional payoff over those that confer future advantage. Studies have suggested, however, that there is heterogeneity in change over time, with both increasing and decreasing profiles of social integration (Bassuk, Glass, \& Berkman, 1999; van Tilburg, 1998) and some variation by gender (Gallant \& Dorn, 2001).

Most longitudinal analyses are short, focus on later life (Cerhan \& Wallace, 1997) and, where they explore change in social integration, focus on specific life events such as marriage, parenthood, divorce or widowhood (Kalmijn, 2012). An exception is the Americans' Changing Lives survey, that has been used to explore comprehensively assessed within-person longitudinal profiles of social integration in over 60 year olds across longer time periods. Women were found to have consistently higher levels of social integration than men over an eight year period (Thomas, 2011a). Two further studies using prospective data over 17 years in this population describe five different profiles of change in social integration and clearly demonstrate the heterogeneity of change in social integration in older age (Thomas, 2011b; 2012).

\section{Patterns of social integration may vary by socio- economic position}

In middle and older age, lower levels of social contact (Krause \& Borawski-Clark, 1995; Van Groenou \& Van Tilburg, 2003; Weyers et al., 2008) and leisure time activity (Scherger, Nazroo, \& Higgs, 2010; Shaw, Krause, Gallant, \& McGeever, 2010) have been found in individuals with lower income or educational attainment. There are mixed findings, however, with other studies finding higher levels of social contact in the lower socio-economic groups (Kubzansky, Berkman, Glass, \& Seeman, 1998) and no work examining change across long periods of time.
Inconsistencies in the relationship between socio-economic position and social integration may arise from differences in the type of group or network measured. Those with lower educational attainment, income or occupational social class are suggested to have more frequent contact with family, but smaller friendship networks and less frequent participation in groups (Granovetter, 1973; Park \& Roberts, 2003; Thomas, 2012). Findings from the British Household Panel Study (in men only) suggest that the types of organisational affiliations also vary with socio-economic position in older age, with higher socio-economic groups being affiliated with civic and religious groups, and lower socio-economic groups being affiliated with social clubs (Perren, Arber \& Davidson, 2003). Socioeconomic inequalities in social integration may depend on age and gender, with smaller inequalities for women (Marmot, Bosma, Hemingway, Brunner, \& Stansfeld, 1997; Van Groenou \& Van Tilburg, 2003) and at younger ages (Stringhini et al., 2012).

The English Longitudinal Study of Ageing has contributed to descriptions of change in social network ties amongst the over 50 years old population, with observations of large variations in individual level change in social integration over eight years (Jivraj, Nazroo, \& Barnes, 2012). When examining the socio-economic factors associated with a move into social detachment, authors found poorer, lower-educated, unhealthy and married individuals to be more likely to become socially detached (with detachment defined as not being a member of a group, not going to cultural event and not having at least weekly contact with a friend or family member).

Most studies have focused on socio-economic indicators in adulthood. but a small number have considered parental education or occupational socio-economic position as a possible determinant of their offspring's social networks in adulthood, although the association with other measures of socio-economic position is found to be stronger (Van Groenou \& Van Tilburg, 2003; Hatch \& Wadsworth, 2008). Several plausible conceptual pathways have been suggested to explain these relationships, with suggestions that socio-economic position at a number of different points in life may independently affect patterns of adult social integration. 
Childhood socio-economic position is related to a number of characteristics of early life living situation, including housing and neighbourhood characteristics (Van de Mheen, Stronks, Van den Bos \& Mackenbach, 1997) family attitudes, beliefs and behaviours (Van Groenou \& Van Tilburg, 2003; Singh-Manoux \& Marmot, 2005) and risk of exposure to early life and family stresses (Lehman, Taylor, Kiefe, \& Seeman, 2005). These may affect an individual's physical and psychosocial development, socialisation and network formation later in life (Repetti, Taylor, \& Seeman, 2002) and may result in decreased interpersonal capacity and networks (Gallo, Espinosa de los Monteros, \& Shivpuri, 2009; Matthews, Gallo, \& Taylor, 2010). Education may directly relate to adult social networks by means of the availability of cognitive resources or skills to develop personal relationships (Van Groenou \& Van Tilburg, 2003). Education may also act as a mediator, explaining the effect of a range of lifetime exposures including anxious or sad adolescent affect on adult social integration (Hatch \& Wadsworth,2008) .Occupational measures of socio-economic position may relate to social networks via available material resources, prestige or social norms that facilitate social integration. It has been suggested that lower socio-economic position may lead to a restricted breadth of relationships (lower relational radius) in order to prevent recognition of social disadvantage or feelings of shame (Weyers et al., 2008), with withdrawal from extended social networks but a stronger reliance on family, kinship and neighbourhood. There may also be a direct effect of poverty on social integration due to lack of financial resources to enable participation.

Whilst there is considerable interest within the epidemiological literature on the possible impact of lack of social integration on morbidity and mortality risk (Fratiglioni, Paillard-borg, \& Winblad, 2004; Gorman \& Sivaganesan, 2007; Holt-Lunstad, Smith, \& Layton, 2010; Seeman et al., 2011; Zunzunegui et al., 2004), it is also likely that the onset of poor health or functional limitation results in declining social integration, and this pathway might also explain why those in lower socio-economic positions are less socially integrated. Participation in the labour market involves a degree of social contact but a clear distinction is drawn in the literature between social engagement or integration, and social interactions that are paid for or enforced (Prohaska, Anderson, \& Binstock, 2012). In line with this body of literature, we elected to focus on social ties and interpersonal aspects of social integration outside of the workplace in the current study, and paid employment was not included as an indicator of social integration. Participation in the labour market has strong and well-established associations with childhood circumstances and education and we were concerned that socio-economic pathways alone should not drive our analyses.

In summary, several studies have considered socio-economic inequalities in social integration cross-sectionally or with short-term follow-up. One recent study examined socio-economic differences in social detachment (Jivraj et al., 2012). Studies have not, however, investigated the relative contribution of indicators of socio-economic position, at different points in the life course, on patterns of change in social integration over mid to late adulthood.

This study examined longitudinal patterns of social integration between the ages of 36 and 6064 , i.e. over a 24 to 28 year period. It aimed to identify profiles of changing social integration and to explore their association with indicators of socioeconomic position at different ages, in a nationally representative cohort of men and women.

\section{Data}

\section{Participants: the 1946 British birth cohort}

The MRC National Survey of Health and Development (NSHD), also known as the 1946 British birth cohort, is a population based birth cohort, originally consisting of a socially stratified sample of 5362 singleton births in one week in March 1946. Data have been collected at 23 points since birth. The main data collections in adulthood were undertaken when study members were 26 , 36, 43, 53 and 60-64 years of age (Wadsworth, Kuh, Richards, \& Hardy, 2006).The cohort generally has high rates of marriage and high marital stability over time.

\section{Measures \\ Social integration}

Consistent with commonly-used definitions of social integration, this study included indicators of marital status, group participation and contact with friends and family. Questions assessing frequency of participation in different clubs or associations 
(group participation), frequency of informal social contact (contact with friends and family), and marital status were included in NSHD at ages 36, 43 and 60-64 years (see Appendix 1) though with slightly different question wording. Frequency of group participation was summarised from items about doing, helping to run or being involved in a number of social, secular and religious group activities. A binary variable (participating in at least one activity weekly or more often, participating less frequently or not at all) was derived for each sweep to allow comparison across the different time points. Frequency of contact with friends or family was summarised from items asking about how often participants met, visited or were visited by friends, parents, partner's parents or other relatives. A binary variable (seeing friends or family three times a month or more, less often or never) was derived at each sweep to maintain consistency across the different time points. It was not possible to quantify how many social contacts were seen at the reported frequencies. Marital status at each sweep was summarised as a binary variable (married, not married). Rates of cohabitation outside of marriage are low in this cohort (about $3.5 \%$ of respondents at age 36 ).

\section{Socio-economic position}

Childhood socio-economic conditions were captured by father's occupation at age 4 (or ages 11 or 15 if this was missing, $n=54)$. Occupations were coded according to the UK Registrar General's Social Class scheme: professional; managerial and technical; skilled (non-manual); skilled (manual); partly skilled; and unskilled (Galobardes, Shaw, Lawlor, Lynch, \& Davey Smith, 2006). Educational attainment was measured as highest recorded qualification at age 26, categorised as none, below secondary, O-level or equivalent (usually attained at age 16), and A-level (High School) or above (usually attained at age 18 or older). Early-adult socioeconomic position was captured as head of household occupation at age 36 (defined at this time as male occupation or own if there was no male in the household). Again, this was coded according to the UK Registrar General's Social Class scheme.

\section{Statistical methods}

Bivariate associations between each measure of socio-economic position and frequent group participation, frequent contact with friends and family and marital status were examined separately for men and women. The latent class analysis used data on three observed categorical indicators of social integration (group participation, contact with friends or family and marital status) at three time points, to identify unobserved profiles of social integration from ages 36 to 60-64. Individuals were grouped according to the similarity of their responses to identify 'classes' of people within the study population. A priori, the number of classes (or profiles of social integration) was unknown so models with an increasing number of classes were fitted to the data, and model selection was conducted via comparison of Bayesian Information Criterion (BIC) values as recommended by Nylund, Asparouhov, and Muthén (2007). To assess the quality of the classification we considered the model's entropy. The entropy is a function that takes values between $O$ and 1 , with high values indicating high certainty of classification. Latent class analysis and mixture modelling was performed in MPlus (version 5). All other analyses were performed in STATA version 12.

The association of childhood, educational and early adult measures of socio-economic position with classification of the different adult profiles of social integration was explored in the latent class model. This one step approach was chosen in preference to a two stage approach (using likely class membership as an outcome in multinomial regression) as it has been shown to be more sensitive to detection of effect size and is preferable where the number of covariates is small enough to make computation feasible (Clark \& Muthén, 2009; Feingold, Tiberio \& Capaldi, 2014). Models use full information maximum likelihood (FIML) for missing data when deriving social integration profiles, including all individuals who have data on one or more observed variables at one or more time point, and we restricted the analytical sample to those with complete data for covariates (socio-economic position variables). Missing data are assumed to be missing at random (Little \& Rubin, 2002).

\section{Analytic sample}

Of the 2,815 men in the original cohort, 958 (34\%) provided no social integration data because of death or other loss to follow-up, and a further 370 men had incomplete socio-economic data. Thus 1,487 men were included in these analyses (998 
provided social integration data on three occasions, 382 on two occasions and 107 on one occasion). Of the 2,547 cohort women, 719 did not provide social integration data, 386 did not provide socioeconomic data, and 1,442 were included in these analysis. Of these, $1,063(277,102)$ provided social integration data on three (two, one) occasions.

Men included in the model were more likely to have $O$ level or above education ( $57 \%$ compared to $47 \%, p<0.001)$ and more likely to be married $(82 \%$ were married compared to $71 \%, p<0.001$ ) than those not included in analyses. Women included in the model were more likely to be educated to 0 level or above ( $53 \%$ compared to $46 \%, p=0.02$ ) and have frequent friend or family contact $(80 \%$ compared to $72 \%, p=0.01$ ), but had slightly lower head of household occupation (only $9 \%$ were in households headed by a professional compared to $15 \%$ of those not included, $p=0.05$ ). Married people, women with frequent group participation at age 36 and women with frequent contact with friends and family at age 60-64 were over-represented among those with complete socio-economic data $(p<0.05)$. Taken together, this indicates that our analytical sample tended to have more advantaged socioeconomic circumstances and greater social integration than those not included.

\section{Results}

Frequent group participation, frequent contact with friends and family and marital status show variations by age and by gender, as shown in table 1 .

Table 1. Social integration by age and gender

\begin{tabular}{|c|c|c|c|c|c|c|}
\hline & \multicolumn{3}{|c|}{ Males } & \multicolumn{3}{|c|}{ Females } \\
\hline & Age 36 & Age 43 & Age 60-64 & Age 36 & Age 43 & Age 60-64 \\
\hline & $\%(n)$ & $\%(n)$ & $\%(n)$ & $\%(n)$ & $\%(n)$ & $\%(n)$ \\
\hline $\begin{array}{l}\text { Group participation } \\
\text { at least weekly } \\
\text { less than weekly or not at all }\end{array}$ & $\begin{array}{l}74 \text { (1098) } \\
26 \text { (389) }\end{array}$ & $\begin{array}{l}37 \text { (493) } \\
63 \text { (844) }\end{array}$ & $\begin{array}{l}52 \text { (497) } \\
48(596)\end{array}$ & $\begin{array}{l}59(846) \\
41(596)\end{array}$ & $\begin{array}{l}37 \text { (478) } \\
63(825)\end{array}$ & $\begin{array}{l}49(502) \\
51(522)\end{array}$ \\
\hline $\begin{array}{l}\text { Contact with friends and } \\
\text { family } \\
\text { at least weekly } \\
\text { less than weekly or not at all }\end{array}$ & $\begin{array}{l}69 \text { (1031) } \\
31(455)\end{array}$ & $\begin{array}{l}80 \text { (1062) } \\
20(273)\end{array}$ & $\begin{array}{l}67(583) \\
33(282)\end{array}$ & $\begin{array}{l}71(1022) \\
29(416)\end{array}$ & $\begin{array}{l}77(1003) \\
23(295)\end{array}$ & $\begin{array}{l}80(742) \\
20(188)\end{array}$ \\
\hline $\begin{array}{r}\text { Married } \\
\text { Not married }\end{array}$ & $\begin{array}{l}84(1252) \\
16(235)\end{array}$ & $\begin{array}{l}82(1101) \\
18(238)\end{array}$ & \begin{tabular}{|l|}
82 (776) \\
$18(166)$
\end{tabular} & $\begin{array}{l}86 \text { (1245) } \\
14 \text { (197) }\end{array}$ & $\begin{array}{l}81(1062) \\
19(242)\end{array}$ & $\begin{array}{l}75 \text { (752) } \\
25 \text { (248) }\end{array}$ \\
\hline
\end{tabular}

Frequent group participation was most prevalent at age 36 for both men and women, with $74 \%$ and $59 \%$ participating in activities once a week or more respectively. Frequent participation fell at age 43 (only $37 \%$ of both genders reported participating once a week or more) but increased again at age $60-64$ (52\% of men and $49 \%$ of women participated at least once a week). A different pattern was seen for frequent contact with friends and family, with the highest rates of weekly contact being at age 43 for men and 60-64 for women. There were gender differences in social integration although these varied at different ages. Men had more frequent group participation than women at age 36 , but no difference in group participation was found at other ages. At age 60-64, a higher proportion of women had at least weekly contact with friends or family than men $(80 \%$ compared to $67 \%, p<0.001)$. Men were more likely than women to be married at age $60-64$ (82\% compared to $75 \%$, $\mathrm{p}<0.001$ ).

Levels of educational attainment and age 36 socio-economic position were lower for women than for men (Table 2). At age 36, frequent group participation was not associated with socioeconomic indicators. Frequent contact with friends and family at age 36 was more prevalent among men and women in lower socio-economic positions on all three indicators. Being married at age 36 was more prevalent among men with higher education and higher early adult socio-economic position (occupation at age 36). 
Table 2: Socio-economic position and social integration at age 36 and 60-64

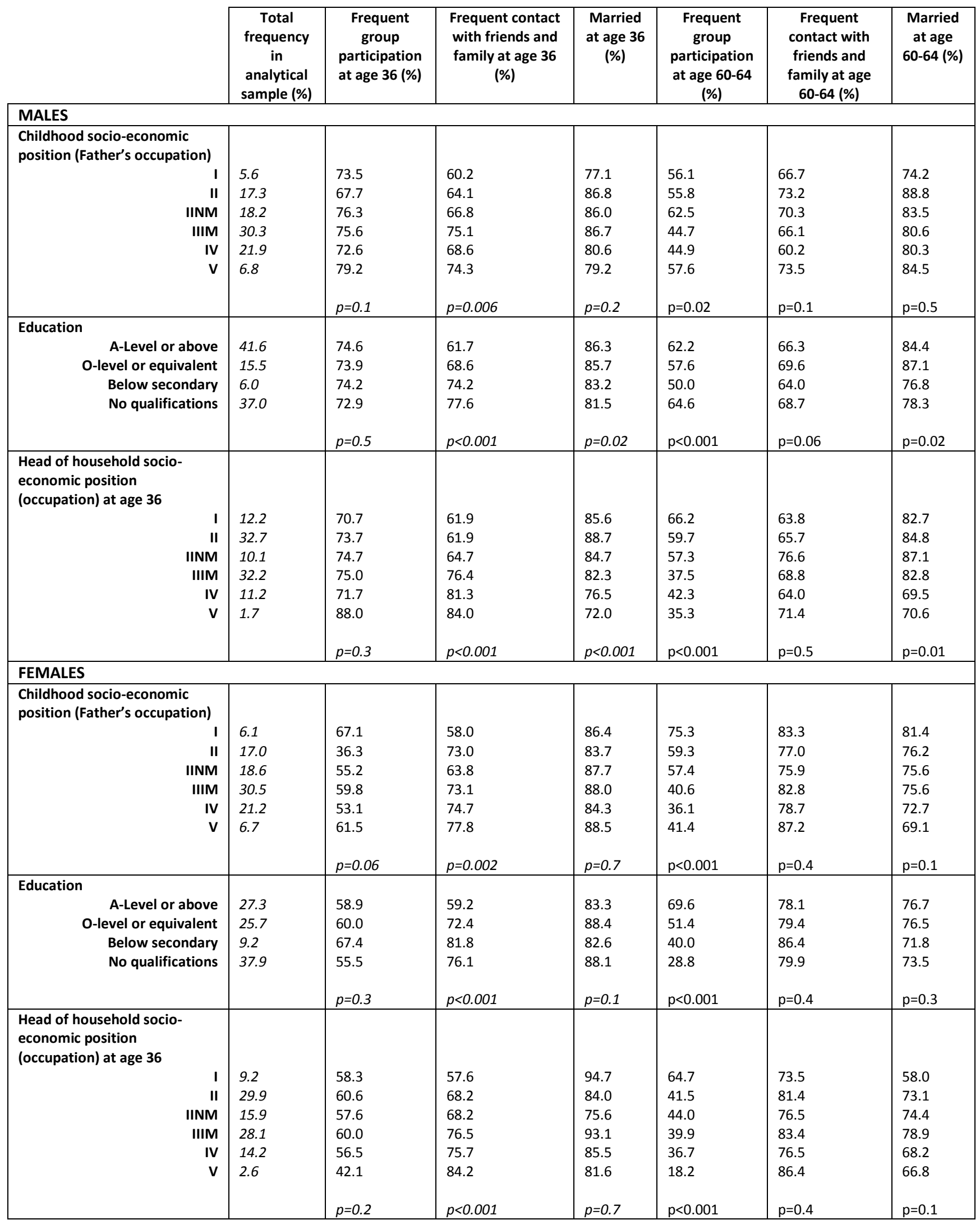

Notes. \% shown for the total analytic sample are the proportion with different socio-economic position. \%s shown for the other subgroups are the proportions of that social class reporting weekly or more social contact or group participation. P-values are from test for linear trend across socio-economic groups. 
By age 60-64, test for linear trend indicated a general pattern of lower group participation in the more socio-economically disadvantaged groups. However, there was indication of non-linearity by father's occupation and educational attainment among men, with those in the middle socioeconomic positions having the lowest frequent group participation. Frequent contact with friends and family at age 60-64 was not socio-economically patterned. Marriage at age 60-64 was less prevalent among more socio-economically disadvantaged men.
Longitudinal profiles of social integration - men

A model with four latent class profiles of social integration between ages 36 and 60-64 provided the best fit to the data in men (see Appendix 2 for fit statistics). The profiles of observed variables within each class are shown in figure 1 . For men, the entropy was 0.569 which, whilst acceptable, demonstrates some uncertainty in class classification (0.6 is considered good, 0.5 poor)(Asparouhov \& Muth, 2014).

\section{Figure 1. Male profiles of social integration}

"High and maintained, married men" (36\%)

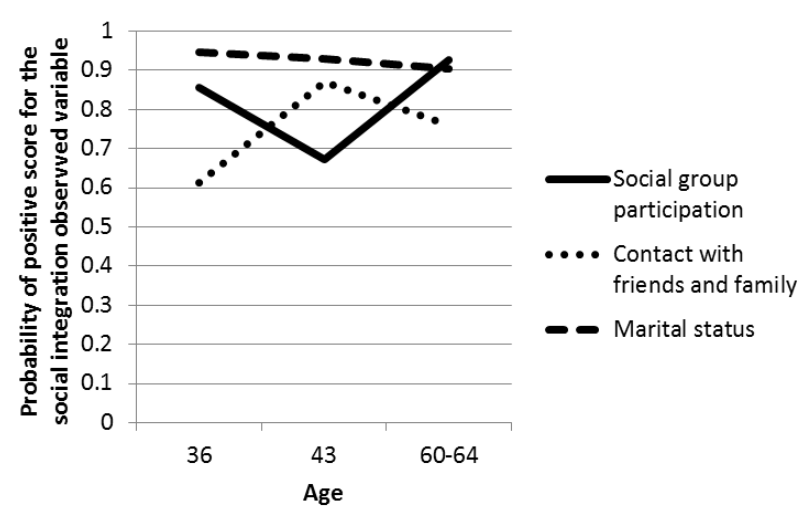

“Declining, unmarried men" (14\%)

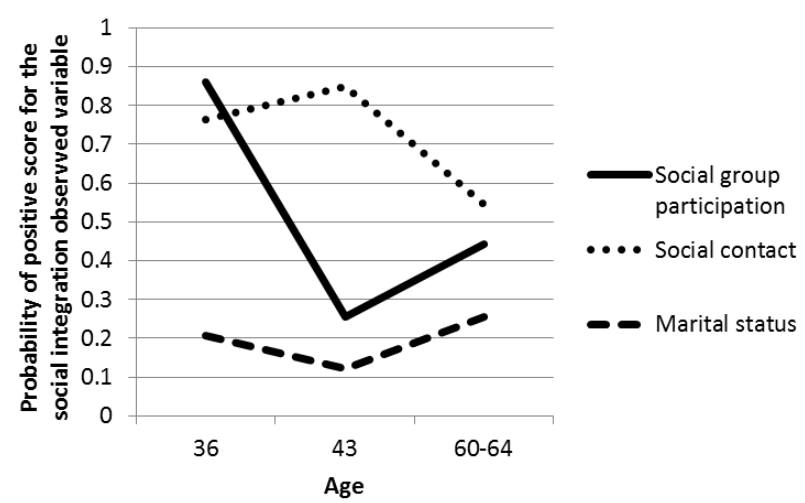

Notes. *denotes reference class in latent class model.

The profile of declining married social integration was taken as the reference in the latent class regression analyses, as it was large in size and had a comparable group among women (see next section). Each step increase in educational attainment was associated with an odds ratio of 1.64 (that is, a 64\% higher likelihood) of following the profile, with high and maintained married social
"Medium and maintained, married men" (20\%)

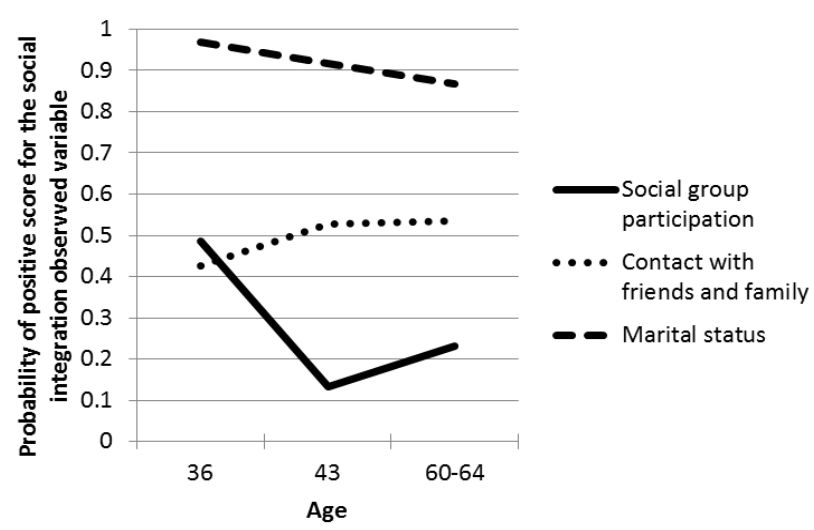

“Declining, married men” (30\%) *

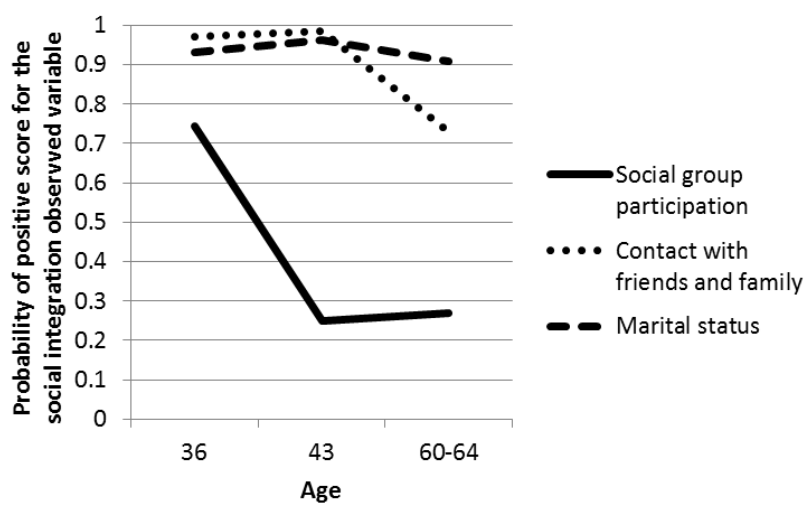

integration compared to the profile of decline. Higher head of household occupation at age 36 was also associated with higher odds of being "high and maintained, married" and "medium and maintained, married", though only the latter attained statistical significance at the $5 \%$ level. No relationship was found between childhood socioeconomic position and men's social integration. 
Table 3. Socio-economic position and profile of social integration for men

\begin{tabular}{|l|l|l|l|}
\cline { 2 - 4 } \multicolumn{1}{c|}{} & $\begin{array}{l}\text { Father's occupation } \\
\text { odds ratio (95\% Cl) }\end{array}$ & $\begin{array}{l}\text { Education at age 26 } \\
\text { odds ratio (95\% Cl) }\end{array}$ & $\begin{array}{l}\text { Head of household } \\
\text { occupation at age 36 } \\
\text { odds ratio (95\% Cl) }\end{array}$ \\
\hline High and maintained, married men (36\%) & $0.92(0.75$ to 1.13$)$ & $1.64(1.33$ to 2.03)* & 1.62 (0.89 to 2.96) \\
\hline Medium and maintained, married men (20\%) & $1.01(0.76$ to 1.34$)$ & $1.07(0.67$ to 1.71$)$ & 1.71 (1.28 to 2.26$)^{*}$ \\
\hline Declining, unmarried (14\%) & $0.97(0.79$ to 1.2$)$ & $1.19(0.95$ to 1.50$)$ & 1.09 (0.71 to 1.66$)$ \\
\hline Declining, married (30\%) & 1 & 1 & 1 \\
\hline
\end{tabular}

Note. * represents $p \leq 0.05$

\section{Longitudinal profiles of social integration - women}

The model fit criteria in the latent class analysis for women identified that the model that best fitted the data had five classes (see Appendix 2) but the difference between the values of BIC was small and, as recommended (Muthen \& Muthen, 2007), did not justify the reduction in parsimony and entropy, so a four class model was chosen; i.e. four profiles of social integration were identified between ages 36 and 60-64 (Figure 2). Class classification was good with entropy of 0.720 .

Figure 2. Female profiles of social integration:

"High and maintained, unmarried women" (8\%)

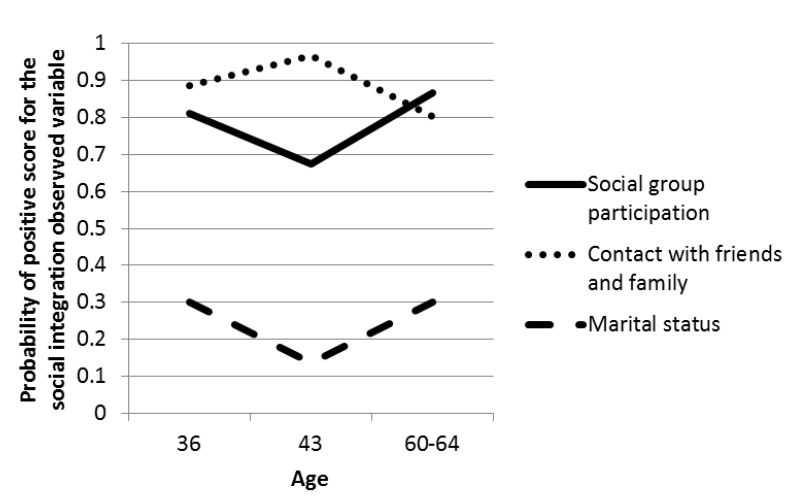

"Declining group participation, unmarried" (10\%)

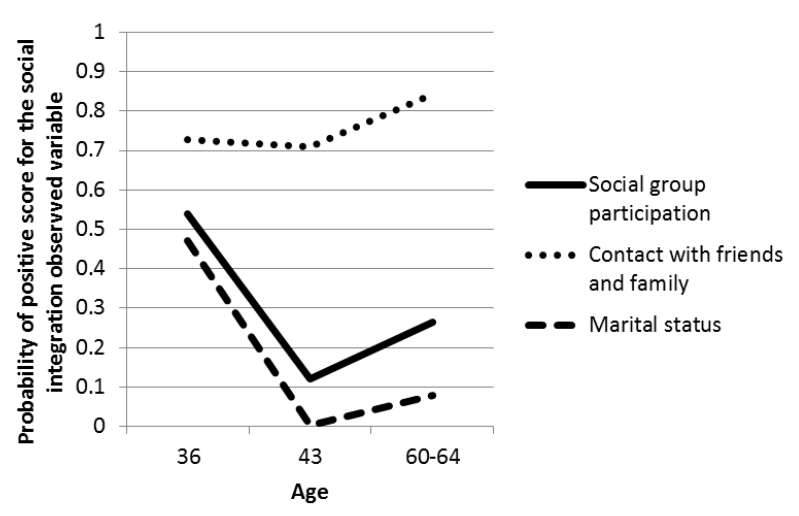

Note. *denotes reference class in latent class model
"High and maintained, married women" (29\%)

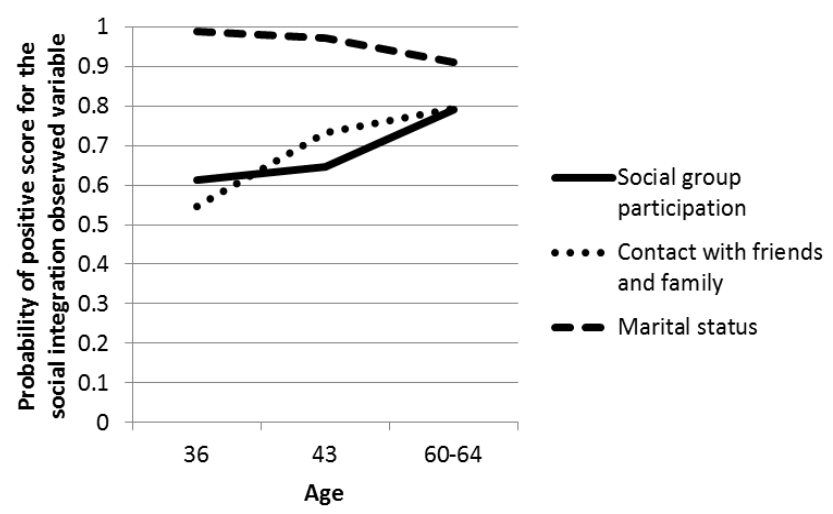

"Declining group participation, married" (53\%) *

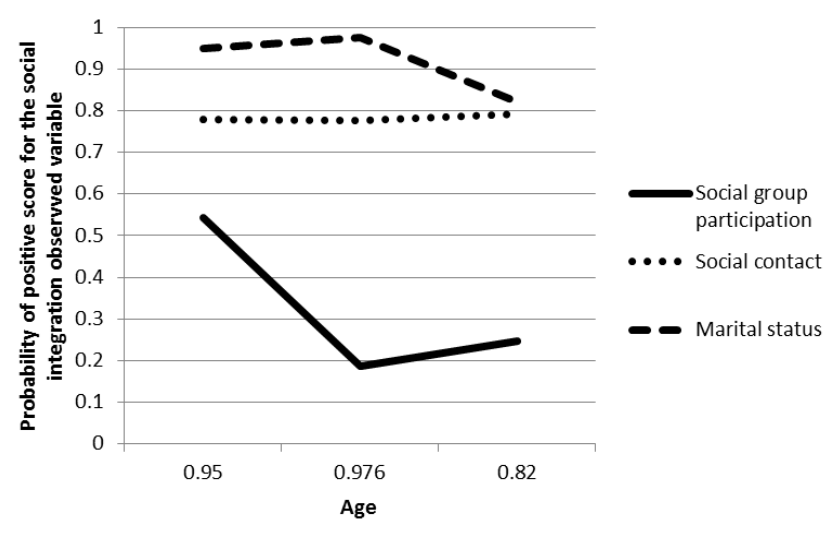


The "declining group participation, married" was used as the reference category. Women with higher education were more likely to experience high and maintained social integration between ages 36 and 60-64 (Table 4). Each step increase in educational attainment was associated with an odds ratio of 2.89 (that is $189 \%$ higher likelihood) of being in the "high and maintained, unmarried" profile and 2.60 (95\% confidence interval 1.53 to 4.40 ) of being in the "high and maintained, married" profile compared to being in the "declining group participation, married" profile, independently of other socio-economic indicators. Socio-economic position at age 36 was also related to the likelihood of following these two profiles. Higher childhood socio-economic position was associated with greater likelihood of being in the "high and maintained, unmarried" profile of social integration compared to the "declining group participation, married" profile.

Table 4. Socio-economic position and profile of social integration for women

\begin{tabular}{|l|l|l|l|}
\cline { 2 - 4 } \multicolumn{1}{c|}{} & $\begin{array}{l}\text { Father's occupation } \\
\text { odds ratio }(\mathbf{9 5 \%} \mathrm{CI})\end{array}$ & $\begin{array}{l}\text { Education at age 26 } \\
\text { odds ratio }(\mathbf{9 5 \%} \mathrm{Cl})\end{array}$ & $\begin{array}{l}\text { Head of household } \\
\text { occupation at age } 36 \\
\text { odds ratio }(\mathbf{9 5 \%} \mathrm{Cl})\end{array}$ \\
\hline High and maintained, unmarried (8\%) & $1.32(1.02 \text { to } 1.71)^{*}$ & $2.89(1.62 \text { to } 5.18)^{* *}$ & $1.31(1.03 \text { to } 1.67)^{*}$ \\
\hline High and maintained, married (29\%) & $1.13(0.91$ to 1.40$)$ & $2.60(1.53 \text { to } 4.40)^{* *}$ & $1.62(1.21 \text { to } 2.16)^{*}$ \\
\hline $\begin{array}{l}\text { Declining group participation, unmarried } \\
(\mathbf{1 0 \% )}\end{array}$ & $0.90(0.71$ to 1.13$)$ & $1.01(0.78$ to 1.31$)$ & $1.06(0.81$ to 1.38$)$ \\
\hline Declining group participation, married (53\%) & 1 & 1 & 1 \\
\hline
\end{tabular}

Notes. ${ }^{*}$ demotes $p \leq 0.05, * *$ denotes $p \leq 0.001$

\section{Discussion}

Within this cohort, multiple profiles of change in social integration between ages 36 and 60-64 were identified, indicating that people do not all experience the same changes in social integration as they age. This confirms recent work undertaken in a US sample of over 60s (Thomas, 2012). For both men and women, group participation changed more with age than either marital status or contact with friends of family. This is consistent with previous research that has identified informal social networks to be more stable over time than civic or leisure activities (Jivraj et al., 2012).

When comparing the four profiles identified for men, higher educational attainment was associated with a higher odds of having high and maintained social integration, compared to experiencing a profile of decline. Higher head of household occupation was also associated with a higher odds of following a profile of "medium and maintained, married men"). No relationship was identified between men's early childhood socio-economic position and the profiles of social integration that followed, suggesting that the socio-economic variables that may affect men's patterns of change in social integration over these ages involve exposures during adolescence or adulthood.

For women, indicators of higher socio-economic position from childhood and adulthood were associated with greater likelihood of maintaining social integration between ages 36 and 60-64. Multiple pathways may be in operation to link socio-economic position and social integration in later life, with early life experiences having a lasting impact on women's social integration in later life. Our analyses suggest that childhood socioeconomic position was somewhat less strongly associated with social integration profiles than was age 36 socio-economic position, though note that at least some of any causal effect of childhood socioeconomic position would be expected to operate through education and adult occupational status which were controlled for here. This is consistent with Van Groenou \& Van Tilburg (2003) who found that network size in older age was associated with the adult household's, but not father's, socioeconomic position. The strength of association between socio-economic position, especially 
education, and patterns of social integration for women is novel, as previous research suggests that relationships between socio-economic position and social integration may be weak for women (Marmot, Bosma, Hemingway, Brunner, \& Stansfeld, 1997; Van Groenou \& Van Tilburg, 2003).

Higher wealth and education at baseline has previously been suggested to be protective against declining social integration or social detachment (Jivraj et al., 2012) but this is the first study to find multiple measures of socio-economic position across childhood and early adulthood to be independently associated with changes in social integration across adulthood. Considering the findings within a social capital framework (Putnam, 2000), group participation may be viewed as a type of bridging social capital, related to access to resources, whereas social contact with friends and family can be viewed as bonding social capital, providing contact between similar individuals but accessing more restricted forms of support. The emergence of socio-economic differences in social integration by early old age may represent differences in the availability of resources, and potentially be important for health and wellbeing within this age group.

\section{Strengths and limitations}

This is the first study to identify an independent relationship between multiple measures of socioeconomic position and the change in social integration experienced during mid to late adulthood. The use of a data-driven approach such as latent class analysis allows consideration of patterns of change in the components of social integration, patterns that would be masked by the use of a summary index. This is also the first study to take a longitudinal approach to the measurement of both socio-economic position and social integration, considering socio-economic characteristics at multiple points through to early adulthood and social integration for almost thirty years of follow up.

The study does, however, have a number of limitations. There were differences in item wording and response categories (see Appendix 1) which may have affected responses, in particular regarding the lower group participation at age 43, where items were more specific than in other sweeps. Dichotomising the observed variables was necessary for data harmonization but this lost some detail and it was not possible to explore patterns of change in different types of relationship (e.g. kin and non-kin) or different groups or activities (e.g. leisure and civic). The analysis treated change in each social integration indicator independently and did not explore the impact of life events such as widowhood or divorce on social contact and group participation. The 'not married' group includes never married, widowed and divorced, and these potentially have different profiles of other social integration indicators including informal contact with friends and family, and social group participation. The full information maximum likelihood method used here, in common with multiple imputation approaches, assumed the data to be missing at random. Our analytical sample appeared to overrepresent more socio-economically advantaged and socially integrated study members, but we are not able to know whether associations between socio-economic exposures and integration are similar amongst excluded individuals. This is a data-driven approach to summarising multiple variables, and emerging latent classes will depend on the analytic sample. Additionally, the models for men did not have high entropy, which means that there may be uncertainty associated with class allocation. It should be acknowledged that, although data covers a 30-year time period, there are only 3 observations of each indicator of social integration.

This study aimed to consider the structural dimensions of social relationships as the data on functional measures were not available over such a long time period. Considering patterns of change in functional social support would provide a more detailed picture of the changes in social relationships over time and it would be useful to see this developed further in future research. As already discussed, and in line with much of the past literature on this topic, we have not included work contacts within our definition of social integration. Different changes in work role and work-related social contacts across the socioeconomic gradient may be related to the changes in non-work-related social integration observed here. Declining health or the onset of limitations may be another key pathway that we have not explored. 


\section{Conclusions}

The study highlights the higher risk of declining social integration amongst those with lower socioeconomic position. Having positive social relationships is a key component of quality of life as defined by older people (Bowling \& Gabriel, 2007) and lack of social integration is associated with an increased likelihood of loneliness (Wenger, Daviesj, Shahtahmasebi, \& Scott, 1996), morbidity, mortality and institutionalisation (Nicholson, 2012; Steptoe,
Shankar, Demakakos, \& Wardle, 2013). With social integration increasingly viewed as a resource for healthy ageing, this study supports a growing body of literature highlighting the importance of fostering social integration in later life (Bowling, Holt-lunstad, Scharf, \& Walker, 2012; Gorman \& Sivaganesan, 2007; Social Care Institute for Excellence, 2011) and provides evidence of the potential socio-economic inequalities in social integration in later life.

\section{References}

Asparouhov, T., \& Muth, B. (2014). Auxiliary Variables in Mixture Modeling : 3-Step Approaches Using Mplus. Structural Equation Modelling: a Multidisciplinary Journal, 21, 1-13.

Bassuk, S., Glass, T., \& Berkman, L. (1999). Social disengagement and incident cognitive decline in community-dwelling elderly persons. Annals of Internal Medicine, 131(3), 165-173. http://dx.doi.org/10.7326/0003-4819-131-3-199908030-00002

Berkman, L. F., Glass, T., Brissette, I., \& Seeman, T. E. (2000). From social integration to health: Durkheim in the new millennium. Social Science \& Medicine, 51(6), 843-57. http://dx.doi.org/10.1016/S0277-9536(00)00065-4

Berkman, L. F. \& Syme, S. L. (1979). Social networks, host resistance, and mortality: a nine year follow-up study of Alameda County residents. American Journal of Epidemiology, 109(2), 186-204.

Berkman, L. F. Melchior, M. Chastang, J. F., Niedhammer, I., Leclerc, A., Goldberg, M.. (2004). Social integration and mortality: a prospective study of French employees of electricity of France-gas of France: The GAZEL cohort. American Journal of Epidemiology, 159(2), 167-174. http://dx.doi.org/10.1093/aje/kwh020

Bowling, A., \& Gabriel, Z. (2007). Lay theories of quality of life in older age. Ageing and Society, 27(06), 827848. http://dx.doi.org/10.1017/S0144686X07006423

Bowling, A., Holt-lunstad, J., Scharf, T., \& Walker, A. (2012). Loneliness: the state we 're in. A report of evidence compiled for the Campaign to End Loneliness. http://campaigntoendloneliness.org/toolkit/download/loneliness-the-state-were-in/

Carstensen, L., Isacowitz, D., \& Charles, S. (1999). Taking time seriously: a theory of socioemotional selectivity. American Psychologist, 54(3), 165-181. http://dx.doi.org/10.1037/0003-066X.54.3.165

Cerhan, J. R., \& Wallace, R. B. (1997). Change in social ties and subsequent mortality in rural elders. Epidemiology, 8(5), 475-481. http://dx.doi.org/10.1097/00001648-199709000-00001

Clark, S. L., \& Muthén, B. (2009). Relating latent class analysis results to variables not included in the analysis. Retrieved from www.statmodel.com/downloads/relatinglca.pdf

Feingold, A. Tiberio, S. Capaldi, D. (2014). New approaches to examining associations with latent categorical variables: applications to substance use and aggression. Psychology of Addictive Behaviours, 28(1), 257-67. http://dx.doi.org/10.1037/a0031487

Fothergill, K. E., Ensminger, M. E., Robertson, J., Green, K. M., Thorpe, R. J., \& Juon, H.-S. (2011). Effects of social integration on health: A prospective study of community engagement among AfricanAmerican women. Social Science \& Medicine, 72(2), 291-8. http://dx.doi.org/10.1016/j.socscimed.2010.10.024

Fratiglioni, L., Paillard-borg, S., \& Winblad, B. (2004). An active and socially integrated lifestyle in late life might protect against dementia. The Lancet, Neurology, 4(Box 6401), 343-353. http://dx.doi.org/10.1016/S1474-4422(04)00767-7

Gallant, M. P., \& Dorn, G. P. (2001). Gender and race differences in the predictors of daily health practices among older adults. Health Education Research, 16(1), 21-31. http://dx.doi.org/10.1093/her/16.1.21

Gallo, L. C., Espinosa de los Monteros, K., \& Shivpuri, S. (2009). Socioeconomic status and health: what is the role of reserve capacity? Current Directions in Psychological Science, 18(5), 269-274. http://dx.doi.org/10.1111/j.1467-8721.2009.01650.x

Galobardes, B., Shaw, M., Lawlor, D. A, Lynch, J. W., \& Davey Smith, G. (2006). Indicators of socioeconomic position (part 2). Journal of Epidemiology and Community Health, 60(2), 95-101.

http://dx.doi.org/10.1136/jech.2004.028092 
Gorman, B. K., \& Sivaganesan, A. (2007). The role of social support and integration for understanding socioeconomic disparities in self-rated health and hypertension. Social Science \& Medicine, 65(5), 958-75. http://dx.doi.org/10.1016/i.socscimed.2007.04.017

Granovetter, M. S. The strength of weak ties. American Journal of Sociology, 78(6), 1360-1380 http://dx.doi.org/10.1086/225469

Hatch, S. L., \& Wadsworth, M. E. (2008). Does adolescent affect impact adult social integration? Evidence from the British 1946 birth cohort. Sociology, 42(1), 155-177. http://dx.doi.org/10.1177/0038038507087358

Holt-Lunstad, J., Smith, T. B., \& Layton, J. B. (2010). Social relationships and mortality risk: a meta-analytic review. Public Library of Science Medicine, 7(7), e1000316.

Jivraj, S., Nazroo, J., \& Barnes, M. (2012). 3. Change in social detachment in older age in England. In The Dynamics of Ageing: Evidence From the English Longitudinal Study of Ageing 2002-2010 48-97.

Kalmijn, M. (2012). Longitudinal analyses of the effects of age, marriage, and parenthood on social contacts and support. Advances in Life Course Research, 17(4), 177-190. http://dx.doi.org/10.1016/j.alcr.2012.08.002

Krause, N., \& Borawski-Clark, E. (1995). Social class differences in social support among older adults. The Gerontologist, 35(4), 498-508. http://dx.doi.org/10.1093/geront/35.4.498

Kubzansky, L. D., Berkman, L. F., Glass, T. a, \& Seeman, T. E. (1998). Is educational attainment associated with shared determinants of health in the elderly? Findings from the MacArthur Studies of Successful Aging. Psychosomatic Medicine, 60(5), 578-85. http://dx.doi.org/10.1097/00006842199809000-00012

Lehman, B. J., Taylor, S. E., Kiefe, C. I., \& Seeman, T. E. (2005). Relation of childhood socioeconomic status and family environment to adult metabolic functioning in the CARDIA study. Psychosomatic Medicine, 67(6), 846-54. http://dx.doi.org/10.1097/01.psy.0000188443.48405.eb

Little, R. J. A., \& Rubin, D. B. (2002). Statistical analysis with missing data, second edition. Hoboken, New Jersey: Wiley.

Marmot, M. G., Bosma, H., Hemingway, H., Brunner, E., \& Stansfeld, S. (1997). Contribution of job control and other risk factors to social variations in coronary heart disease incidence. Lancet, 350(9073), 235-9. http://dx.doi.org/10.1016/S0140-6736(97)04244-X

Matthews, K. a, Gallo, L. C., \& Taylor, S. E. (2010). Are psychosocial factors mediators of socioeconomic status and health connections? A progress report and blueprint for the future. Annals of the New York Academy of Sciences, 1186, 146-73. http://dx.doi.org/10.1111/j.1749-6632.2009.05332.x

Muthen, B., \& Muthen, L. (2007). MPlus User Forum: difference in BIC values. Retrieved from http://www.statmodel.com/discussion/messages/23/2232.html

Nicholson, N. R. (2012). A review of social isolation: an important but underassessed condition in older adults. The Journal of Primary Prevention, 33(2-3), 137-52. http://dx.doi.org/10.1007/s10935-0120271-2

Nylund, K. L., Asparouhov, T., \& Muthén, B. O. (2007). Deciding on the number of classes in latent class analysis and growth mixture modeling: A Monte Carlo simulation study. Structural Equation Modeling: A Multidisciplinary Journal, 14(4), 535-569. http://dx.doi.org/10.1080/10705510701575396

Park, A. Roberts, C. (2003). The ties that bind. In British Social Attitudes: The 19th report. London: Sage.

Perren, K., Arber, S., \& Davidson, K. (2003). Men's organisational affiliations in later life: the influence of social class and marital status on informal group membership. Ageing and Society, 23(1), 69-82. http://dx.doi.org/10.1017/S0144686X02001034

Prohaska, T. R., Anderson, L. A., \& Binstock, R. H. (2012). Public health for an ageing society. Baltimore: The Johns Hopkins University Press.

Putnam, R. (2000). Bowling alone: the collapse and revival of American community. New York: Simon and Schuster.

Repetti, R., Taylor, S., \& Seeman, T. (2002). Risky families: family social environments and the mental and physical health of offspring. Psychological Bulletin, 128(2), 330-366. http://dx.doi.org/10.1037/0033-2909.128.2.330

Scherger, S., Nazroo, J., \& Higgs, P. (2010). Leisure activities and retirement: do structures of inequality change in old age? Ageing and Society, 31(01), 146-172. http://dx.doi.org/10.1017/S0144686X10000577

Seeman, T. E., Miller-Martinez, D. M., Stein Merkin, S., Lachman, M. E., Tun, P. A, \& Karlamangla, A. S. (2011). Histories of social engagement and adult cognition: midlife in the U.S. study. The Journals of Gerontology. Series B, Psychological Sciences and Social Sciences, 66 Suppl 1, i141-52. http://dx.doi.org/10.1093/geronb/gbq091

Shaw, B. A., Krause, N., Gallant, M., \& McGeever, K. (2010). Age Differences and Social Stratification in the Long-Term Trajectories of Leisure-Time Physical Activity. Journal of Gerontology: Social Sciences, 65B(6), 756-766. http://dx.doi.org/10.1093/geronb/gbq073 
Singh-Manoux, A., \& Marmot, M. (2005). Role of socialization in explaining social inequalities in health. Social Science \& Medicine, 60(9), 2129-33. http://dx.doi.org/10.1016/j.socscimed.2004.08.070

Social Care Institute for Excellence. (2011). Preventing loneliness and social isolation : interventions and outcomes. Retrieved from http://www.scie.org.uk/publications/briefings/files/briefing39.pdf

Steptoe, A., Shankar, A., Demakakos, P., \& Wardle, J. (2013). Social isolation, loneliness, and all-cause mortality in older men and women. Proceedings of the National Academy of Sciences of the United States of America, 2013, 1-5.

Stringhini, S., Berkman, L., Dugravot, A., Ferrie, J. E., Marmot, M., Kivimaki, M., \& Singh-Manoux, A. (2012). Socioeconomic status, structural and functional measures of social support, and mortality: The British Whitehall II Cohort Study, 1985-2009. American Journal of Epidemiology, 175(12), $1275-83$. http://dx.doi.org/10.1093/aje/kwr461

Thomas, P. A. (2011a). Gender, social engagement, and limitations in late life. Social Science \& Medicine, 73(9), 1428-35. http://dx.doi.org/10.1016/j.socscimed.2011.07.035

Thomas, P. A. (2011b). Trajectories of social engagement and limitations in late life. Journal of Health and Social Behavior, 52(4), 430-43. http://dx.doi.org/10.1177/0022146511411922

Thomas, P. A. (2012). Trajectories of social engagement and mortality in late life. Journal of Aging and Health, 24(4), 547-68. http://dx.doi.org/10.1177/0898264311432310

Van de Mheen, H., Stronks, K., Van den Bos, J., \& Mackenbach, J. (1997). The contribution of childhood environment to the explanation of socio-economic inequalities in health in adult life: a retrospective study. Social Science \& Medicine, 44(1), 13-24. http://dx.doi.org/10.1016/S0277-9536(96)00090-1

Van Groenou, M. I. B., \& Van Tilburg, T. (2003). Network size and support in old age: differentials by socioeconomic status in childhood and adulthood. Ageing and Society, 23(5), 625-645. http://dx.doi.org/10.1017/S0144686X0300134X

Van Tilburg, T. (1998). Losing and gaining in old age: changes in personal network size and social support in a four-year longitudinal study. The Journals of Gerontology. Series B, Psychological Sciences and Social Sciences, 53(6), S313-23. http://dx.doi.org/10.1093/geronb/53B.6.S313

Vonneilich, N., Jöckel, K.-H., Erbel, R., Klein, J., Dragano, N., Weyers, S., Moebus, S., Siegrist, J., von dem Knesebeck, O. (2011). Does socioeconomic status affect the association of social relationships and health? A moderator analysis. International Journal for Equity in Health, 10(1), 43-51. http://dx.doi.org/10.1186/1475-9276-10-43

Wadsworth, M., Kuh, D., Richards, M., \& Hardy, R. (2006). Cohort Profile: The 1946 National Birth Cohort (MRC National Survey of Health and Development). International Journal of Epidemiology, 35(1), 49-54. http://dx.doi.org/10.1093/ije/dyi201

Wenger, G. C., Daviesj, R., Shahtahmasebi, S., \& Scott, A. (1996). Social isolation and loneliness in old age: review and model refinement. Ageing and Society, 16, 333-358. http://dx.doi.org/10.1017/S0144686X00003457

Weyers, S., Dragano, N., Möbus, S., Beck, E.-M., Stang, A., Möhlenkamp, S., Jockel, K. H., Erbel, R., Siegrist, J. (2008). Low socio-economic position is associated with poor social networks and social support: results from the Heinz Nixdorf Recall Study. International Journal for Equity in Health, 7(13). http://dx.doi.org/10.1186/1475-9276-7-13

Zunzunegui, M. V, Koné, A, Johri, M., Béland, F., Wolfson, C., \& Bergman, H. (2004). Social networks and self-rated health in two French-speaking Canadian community dwelling populations over 65. Social Science \& Medicine, 58(10), 2069-81. http://dx.doi.org/10.1016/i.socscimed.2003.08.005 


\section{Appendix 1}

\section{Social integration variables}

\begin{tabular}{|c|c|c|c|}
\hline & 1982 (age 36) & 1989 (age 43) & 2006-2011 (age 60-64) \\
\hline $\begin{array}{l}\text { Frequency of } \\
\text { social group } \\
\text { participation: }\end{array}$ & $\begin{array}{l}\text { Nurse led interviews: } \\
\text { Do you do any of the following in your spare } \\
\text { time and on average in the last year have you } \\
\text { done this at least daily, weekly, less frequently? } \\
\text { (chess bridge or similar, church or religious } \\
\text { activities, going to the theatre concerts, going } \\
\text { to pub/club, helping to run a club or playgroups } \\
\text { or school, local government or trade union or } \\
\text { political work, playing a musical instrument } \\
\text { with others, voluntary social welfare work). } \\
\text { Are there any other things you do with other } \\
\text { people in your spare time that I haven't yet } \\
\text { asked about? What are they and how often? }\end{array}$ & $\begin{array}{l}\text { Nurse led interviews: } \\
\text { In your spare time, do you } \\
\text { help to run or are you } \\
\text { currently involved in any of } \\
\text { the following activities and } \\
\text { do you take part weekly, } \\
\text { monthly or less often? } \\
\text { (Church activities, } \\
\text { playgroup nurseries or } \\
\text { school, local government, } \\
\text { trade unions, voluntary } \\
\text { services, sports clubs, } \\
\text { evening classes/adult } \\
\text { education, other } \\
\text { organisations). }\end{array}$ & $\begin{array}{l}\text { Postal questionnaire: } \\
\text { In your spare time are you } \\
\text { involved in any of the following } \\
\text { activities, if yes have you taken } \\
\text { part in the last } 12 \text { months } \\
\text { weekly, monthly, less often or } \\
\text { never? (Church-related group } \\
\text { or religious activities, job } \\
\text { related association, } \\
\text { recreational groups, civic } \\
\text { political group, other voluntary } \\
\text { work, other groups or clubs, } \\
\text { other social activities). }\end{array}$ \\
\hline $\begin{array}{l}\text { Frequency of } \\
\text { contact with } \\
\text { friends or } \\
\text { family: }\end{array}$ & $\begin{array}{l}\text { Nurse led interviews: } \\
\text { How often do you have friends to spend the } \\
\text { evening with you at home, or to spend some } \\
\text { time at home with you on the weekend? (Once } \\
\text { a week or more often, not more than once a } \\
\text { fortnight, not more than once a month, rarely } \\
\text { or never, unknown). } \\
\text { How often do you see your parents and/or your } \\
\text { wife's/husband's/partner's parents? (Once a } \\
\text { week or more often, not more than once a } \\
\text { fortnight, not more than once a month, rarely } \\
\text { or never, not relevant no parents, unknown). }\end{array}$ & $\begin{array}{l}\text { Nurse led interviews: } \\
\text { On average, how often } \\
\text { would you say you met } \\
\text { friends or relatives socially? } \\
\text { (Never, 1-2 times a month, } \\
\text { 3-5 times a month, 6-10 } \\
\text { times a month, 11-15 times } \\
\text { a month, more than } 15 \\
\text { times a month). }\end{array}$ & $\begin{array}{l}\text { Nurse led interview: } \\
\text { Thinking of all your relatives or } \\
\text { friends, how often do you } \\
\text { regularly visit or are you visited } \\
\text { by these people? } \\
\text { (Never/almost never, once } \\
\text { every few months, about once } \\
\text { a month, about once a week, } \\
\text { almost daily). }\end{array}$ \\
\hline Marital status & $\begin{array}{l}\text { Nurse led interviews: } \\
\text { And so may I just check at the moment you are } \\
\text { single and not living with a partner, single i.e. } \\
\text { never married and living with a partner, } \\
\text { married, widowed and not living with a } \\
\text { partner, separated and not living with a } \\
\text { partner, divorced and not living with a partner, } \\
\text { widowed and living with a partner, separated } \\
\text { or divorced and living with a partner? }\end{array}$ & $\begin{array}{l}\text { Nurse led interviews: } \\
\text { So can I just check, are you } \\
\text { currently single never } \\
\text { married, married, widowed, } \\
\text { separated, divorced? }\end{array}$ & $\begin{array}{l}\text { Postal questionnaire: } \\
\text { So, are you currently single that } \\
\text { is never married, married \& } \\
\text { living with husband/wife, } \\
\text { married \& separated from } \\
\text { husband/wife, divorced, } \\
\text { widowed? }\end{array}$ \\
\hline
\end{tabular}




\section{Appendix 2a}

Table 2a. Latent class analysis fit statistics for social integration for men in the MRC NSHD (age 43 to 60-64)

\begin{tabular}{|l|l|l|l|l|}
\cline { 2 - 6 } \multicolumn{1}{c|}{} & 2 classes & 3 classes & $\mathbf{4}$ classes & $\mathbf{5}$ classes \\
\hline \multicolumn{1}{l|}{ Information criteria } \\
\hline Schwarz's BIC & 12169.5 & 12031.9 & 12023.5 & 12064.9 \\
\hline Smallest class percentage & 16 & 14 & 14 & 7 \\
\hline Entropy $^{\mathrm{b}}$ & 0.823 & 0.613 & 0.569 & 0.587 \\
\hline
\end{tabular}

Abbreviations: BIC, Bayesian Information Criterion

${ }^{a}$ minimum information criterion is shown in italic type

${ }^{b}$ based on estimated posterior class membership probabilities

\section{Appendix 2b}

Table $2 b$. Latent class analysis fit statistics for social integration for women in the MRC NSHD (age 43 to 60-64)

\begin{tabular}{|c|c|c|c|c|c|}
\hline & 2 classes & 3 classes & 4 classes & 5 classes & 6 classes \\
\hline \multicolumn{6}{|l|}{${\text { Information } \text { criteria }^{a}}^{a}$} \\
\hline Schwarz's BIC & 12248.0 & 12077.6 & 12060.8 & 12056.7 & 12112.8 \\
\hline Smallest class percentage & 18 & 16 & 8 & 7 & 7 \\
\hline Entropy $^{b}$ & 0.863 & 0.657 & 0.720 & 0.664 & 0.633 \\
\hline
\end{tabular}

Abbreviations: BIC, Bayesian Information Criterion

${ }^{a}$ minimum information criterion is shown in italic type

${ }^{b}$ based on estimated posterior class membership probabilities 
